\title{
Evaluation of prescription compliance and medication accuracy in a paediatric unit at the Lady Ridgeway Hospital, Colombo
}

\author{
K P N Perera ${ }^{1}$, Sanath P Lamabadusuriya ${ }^{2}$, W Pathirana ${ }^{3}$ \\ Sri Lanka Journal of Child Health, 2004; 33: 73-7
}

(Key words: Prescription compliance, medication accuracy, children)

\begin{abstract}
Objectives To assess variation between prescription intentions and what was actually administered to paediatric patients and the problem of converting adult dosages to paediatric doses in a ward setting.
\end{abstract}

Method A prospective descriptive study was carried out at Ward 01, Lady Ridgeway Hospital, Colombo. Administration of drugs to 170 patients was directly observed and recorded during drug rounds. Converted adult dosages for paediatric administration were analyzed to determine the content of active ingredient per unit dose prepared.

Results In 170 patients observed, correct drugs were administered in every instance except one. At all times drugs were administered via intended route and the timing of drug rounds was capable of accommodating the prescribed dosing frequencies. However in $17.64 \%$ anomalies between prescribed dose and administered dose were encountered for both orally and intravenously administered drugs.

\section{Introduction}

It has long been recognized that the paediatric patient is not simply a "little adult" and should not be dosed or treated in that manner. Pharmacologic management of paediatric patients is a unique and challenging speciality. Many considerations within this population may influence drug recommendations. These factors include a rapidly changing height, weight, body composition and maturity of organ systems to eliminate various drug products. When prescribing, the paediatrician takes all these factors into consideration and it is expected that the nursing staff adhere to these prescription intentions. Prescription intentions/compliance can be categorized into four main sections:

${ }^{1}$ Pharmacy Student, ${ }^{2}$ Dean and Senior Professor of Paediatrics, ${ }^{3}$ Senior Lecturer in Pharmacy, Faculty of Medicine, University of Colombo.

(Received on 29 December2003)
1) Administration of prescribed drug

2) Via the intended route

3) Adherence to correct frequency of administration

4) Administration of accurate dose.

Medication accuracy is especially of great concern when treating paediatric patients. This is mainly due to the absence of paediatric oral preparations while paediatric doses must be obtained from the adult prefabricated dosage forms available. This is true for the vast majority of drugs present in the paediatric ward. This study was carried out to evaluate the accuracy of administration of medication to patients in ward 01 at the Lady Ridgeway Hospital, Colombo.

\section{Design}

A prospective descriptive study.

\section{Method}

During the course of five months (July to November 2002), on two days of the week, in ward 01 at the Lady Ridgeway Hospital, Colombo, the entire procedure of drug administration to 154 patients was directly observed during the morning and afternoon drug rounds. The details of drug administration were recorded on a checklist. The checklist was structured in such a manner as to highlight possible errors that might occur during drug administration. Sixteen patients were followed up at a subsequent drug round to assess if any errors recorded previously, were repeated or rectified. Thus a total of 170 drug administration records were made. Samples of the converted adult dosages for paediatric administration were collected at the bedside and were subjected to chemical analysis to determine the content of active ingredient per converted dose. 


\section{Results}

Only one error was observed out of a total of 446 instances that a drug was administered (from the drug administration records of 170 patients), where a different drug was administered instead of the prescribed drug. This was the administration of normal saline nasal drops instead of oxymetazoline hydrochloride nasal drops. In all instances the drugs were administered via the intended route and dosage form.

When the timings of the drug rounds were considered they were found to be generally capable of accommodating the prescribed dosing frequencies.
However there was one exception - drugs prescribed to be administered eight hourly. The prescription clock (figure 1) illustrates the actual times of drug administration vs. the prescribed times for drug administration. A near twelve hour difference between the final dose of a day and the first dose of the following day can be observed. Thus drug administration was thrice a day (tds) rather than eight hourly. In $3.5 \%$ of the patients a particular drug was crossed out on the bed head ticket (BHT) even though it was not actually administered. This occurred as a result of the nurse first crossing out the times of drug administration on the BHT prior to actual administration, and by carrying out the subsequent administration by memory.

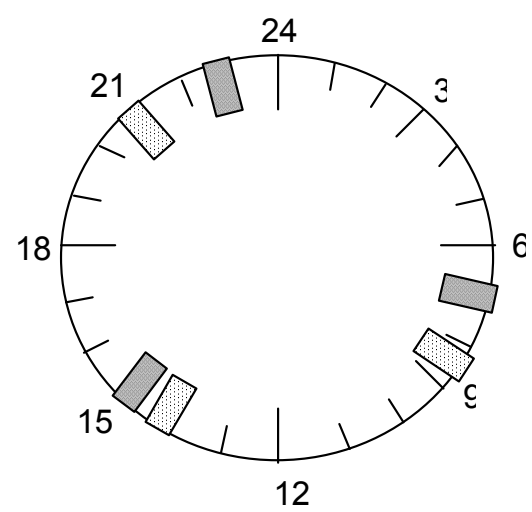

Time prescribed for drug administration

$\therefore:$ Actual time of drug administration

Figure 1.The comparison of the actual times of drug administration vs. the prescribed times for drug administration.

When considering the prescription intentions however the major area of concern appeared to be a lapse in the administration of the accurate dose. From the 170, drug administration records where at least one inaccurate dose was observed for a patient was $17.64 \%$. Inaccurate doses (lower and higher doses against the prescribed dose) were observed for both orally and intravenously (IV) administered drugs. In the majority higher doses were administered for oral drugs while lower doses were administered for IV drugs. Table 1 shows some examples of the inaccurate IV doses administered and Table 2 shows some examples of the inaccurate oral doses administered. With regard to drugs administered IV the errors were mainly observed for gentamicin and benzylpenicillin.
Table 3 shows some examples of the dose divisions required to be made for the accurate administration of medication to the paediatric patient. Table 4 shows the findings of the chemical analysis carried out for the converted adult dosages for paediatric administration. The divided doses were analyzed according to the British Pharmacopoeia. The results indicate that dose accuracy is difficult to achieve where a variation of at least $\pm 10 \%$ against the prescribed dose was observed for the converted doses. In all instances where the patients were followed up in a subsequent drug round $(n=16)$ it was found that the errors previously made were not repeated. 
Table 1

Examples of some inaccurate doses administered intravenously

\begin{tabular}{|c|c|c|c|c|c|c|}
\hline $\begin{array}{c}\text { Name of the } \\
\text { drug }\end{array}$ & Strength & $\begin{array}{l}\text { Amount } \\
\text { of drug } \\
\text { required }\end{array}$ & $\begin{array}{c}\text { Volume } \\
\text { to be } \\
\text { administered } \\
\text { (ml) }\end{array}$ & $\begin{array}{c}\text { Volume } \\
\text { actually } \\
\text { administered } \\
\text { (ml) }\end{array}$ & $\begin{array}{c}\text { Actual } \\
\text { amount } \\
\text { of drug } \\
\text { administered }\end{array}$ & $\begin{array}{l}\% \\
\text { Error }\end{array}$ \\
\hline \multirow[t]{4}{*}{ Gentamicin } & $80 \mathrm{mg} / 2 \mathrm{ml}$ & $7 \mathrm{mg}$ & 0.175 & 0.15 & $6 \mathrm{mg}$ & -14.3 \\
\hline & & $2 \mathrm{mg}$ & 0.05 & 0.02 & $0.8 \mathrm{mg}$ & -60 \\
\hline & & $12 \mathrm{mg}$ & 0.3 & 0.12 & $4.8 \mathrm{mg}$ & -60 \\
\hline & & $7.5 \mathrm{mg}$ & 0.19 & $<0.1$ & $<4 \mathrm{mg}$ & -46.7 \\
\hline \multirow[t]{7}{*}{ Benzylpenicillin } & $600 \mathrm{mg} / 5 \mathrm{ml}$ & $200 \mathrm{mg}$ & 1.67 & 1.5 & $180 \mathrm{mg}$ & -10 \\
\hline & $600 \mathrm{mg} / 4 \mathrm{ml}$ & $1000 \mathrm{mg}$ & 6.66 & 6 & $900 \mathrm{mg}$ & -10 \\
\hline & & $200 \mathrm{mg}$ & 1.3 & 0.5 & $75 \mathrm{mg}$ & -62.5 \\
\hline & & $180 \mathrm{mg}$ & 1.2 & 0.8 & $120 \mathrm{mg}$ & -33.3 \\
\hline & & $480 \mathrm{mg}$ & 3.2 & 3.5 & $525 \mathrm{mg}$ & +9.4 \\
\hline & $1 \mathrm{MU} / 4 \mathrm{ml}$ & $0.4 \mathrm{MU}$ & 1.6 & 1.8 & $0.45 \mathrm{MU}$ & +12.5 \\
\hline & & $0.33 \mathrm{MU}$ & 1.3 & 1.5 & $0.375 \mathrm{MU}$ & +13.6 \\
\hline
\end{tabular}

Table 2

Examples of some inaccurate doses administered orally

\begin{tabular}{|c|c|c|c|c|c|}
\hline $\begin{array}{l}\text { Name of the } \\
\text { drug }\end{array}$ & Strength & $\begin{array}{l}\text { Dose } \\
\text { required }\end{array}$ & $\begin{array}{c}\text { Amount of } \\
\text { drug } \\
\text { administered }\end{array}$ & $\begin{array}{c}\text { Actual } \\
\text { dose } \\
\text { administered }\end{array}$ & $\begin{array}{c}\% \\
\text { Error }\end{array}$ \\
\hline Aspirin & $300 \mathrm{mg}$ & $400 \mathrm{mg}$ & $\begin{array}{l}1 \text { tablet }+1 / 2 \\
\text { tablet }\end{array}$ & $450 \mathrm{mg}$ & +12.5 \\
\hline Benzhexol & $2 \mathrm{mg}$ & $0.25 \mathrm{mg}$ & $1 / 4$ tablet & $0.5 \mathrm{mg}$ & +100 \\
\hline \multirow[t]{2}{*}{ Captopril } & $25 \mathrm{mg}$ & $1 \mathrm{mg}$ & $\begin{array}{c}1 \mathrm{ml} \text { of a } \\
\text { solution of } \\
25 \mathrm{mg} / 5 \mathrm{ml}\end{array}$ & $5 \mathrm{mg}$ & +400 \\
\hline & & $3.125 \mathrm{mg}$ & $1 / 4$ tablet & $6.25 \mathrm{mg}$ & +100 \\
\hline \multirow[t]{2}{*}{ Clonazepam } & $2 \mathrm{mg}$ & $0.25 \mathrm{mg}$ & $\begin{array}{l}1 \text { tablet }+1 / 4 \\
\text { tablet }\end{array}$ & $2.5 \mathrm{mg}$ & +900 \\
\hline & & $0.125 \mathrm{mg}$ & $1 / 4$ tablet & $0.5 \mathrm{mg}$ & +300 \\
\hline Digoxin & $0.05 \mathrm{mg} / \mathrm{ml}$ & $140 \mathrm{mcg}$ & $2.5 \mathrm{ml}$ & $125 \mathrm{mcg}$ & -10.71 \\
\hline
\end{tabular}


Table 3

Some dose divisions required to be made to administer the accurate amount of medication to the patient

\begin{tabular}{|c|c|c|c|}
\hline Name of the drug & Strength & Dose required & $\begin{array}{c}\text { Amount of drug that needs } \\
\text { to be administered }\end{array}$ \\
\hline Aspirin & $300 \mathrm{mg}$ & $\begin{array}{l}25 \mathrm{mg} \\
400 \mathrm{mg}\end{array}$ & $\begin{array}{l}1 / 12 \text { th of a tablet } \\
1 \text { tablet }+1 / 3 \text { rd of a tablet }\end{array}$ \\
\hline Captopril & $25 \mathrm{mg}$ & $\begin{array}{l}3.125 \mathrm{mg} \\
1.2 \mathrm{mg} \\
1 \mathrm{mg}\end{array}$ & $\begin{array}{l}1 / 8 \text { th of a tablet } \\
1 / 20 \text { th of a tablet } \\
1 / 25 \text { th of a tablet }\end{array}$ \\
\hline Clonazepam & $2 \mathrm{mg}$ & $\begin{array}{l}0.125 \mathrm{mg} \\
0.25 \mathrm{mg}\end{array}$ & $\begin{array}{l}1 / 16 \text { th of a tablet } \\
1 / 8 \text { th of a tablet }\end{array}$ \\
\hline Dipyridamole & $25 \mathrm{mg}$ & $15 \mathrm{mg}$ & $3 / 5$ th of a tablet \\
\hline Frusemide & $40 \mathrm{mg}$ & $\begin{array}{l}5 \mathrm{mg} \\
4 \mathrm{mg}\end{array}$ & $\begin{array}{l}1 / 8 \text { th of tablet } \\
1 / 10 \text { th of a tablet }\end{array}$ \\
\hline Phenobarbitone & $\begin{array}{l}60 \mathrm{mg} \\
15 \mathrm{mg}\end{array}$ & $\begin{array}{l}7.5 \mathrm{mg} \\
10 \mathrm{mg}\end{array}$ & $\begin{array}{l}1 / 8 \text { th of a tablet } \\
2 / 3 \text { rd of a tablet }\end{array}$ \\
\hline
\end{tabular}

Table 4

Comparison between the actual amount of active ingredient present in the converted dosage and the prescribed amount

\begin{tabular}{|c|c|c|c|c|c|c|}
\hline $\begin{array}{l}\text { Name of the } \\
\text { drug }\end{array}$ & $\begin{array}{l}\text { No. of } \\
\text { samples } \\
\text { taken from } \\
\text { the bedside }\end{array}$ & $\begin{array}{l}\text { Strength } \\
\text { of the } \\
\text { drug }(\mathrm{mg})\end{array}$ & $\begin{array}{l}\text { Prescribed } \\
\text { amount (mg) }\end{array}$ & $\begin{array}{c}\text { Dose } \\
\text { conversion }\end{array}$ & $\begin{array}{l}\text { Actual } \\
\text { amount } \\
\text { present (mg) }\end{array}$ & $\begin{array}{c}\% \\
\text { Error }\end{array}$ \\
\hline Cloxacillin & 1 & 250 & 62.5 & $\begin{array}{l}1 / 4 \text { of a } \\
\text { capsule }\end{array}$ & 43.77 & -29.97 \\
\hline Frusemide & $\begin{array}{l}1 \\
1\end{array}$ & 40 & 5 & $\begin{array}{c}1 / 8 \text { of a } \\
\text { tablet }\end{array}$ & $\begin{array}{l}6.01 \\
6.09\end{array}$ & $\begin{array}{l}+20.2 \\
+21.8\end{array}$ \\
\hline Salbutamol & $\begin{array}{l}1 \\
1\end{array}$ & 4 & 2 & $\begin{array}{l}1 / 2 \text { of a } \\
\text { tablet }\end{array}$ & $\begin{array}{l}1.51 \\
1.79\end{array}$ & $\begin{array}{l}-24.5 \\
-10.5\end{array}$ \\
\hline
\end{tabular}

\section{Discussion}

Prescription compliance was largely satisfactory with regard to administration of the correct drug via the intended route and dosage form. In the instance where an incorrect drug was administered (normal saline nasal drops instead of oxymetazoline hydrochloride nasal drops) it was one that was unlikely to cause adverse effects.

However dose accuracy is a matter for concern where inaccurate dose administration was $17.64 \%$ for at least one drug prescribed on the BHT for the 170 patients observed. Administration of inaccurate doses for oral drugs mainly occurred when the adult dosage forms were required to be divided to small fractions to obtain the prescribed paediatric doses. This was especially so when the divisions required to be made were smaller than $1 / 4$ of a tablet and therefore difficult to obtain (e.g. 1/8, 1/10,1/12,1/16,1/20,1/25, 1/3, $2 / 3,3 / 5$ of a tablet). In these instances the closest possible divisions were made. Such a situation is not satisfactory and is therefore prone to errors. The 
results of the chemical analysis carried out for some converted adult dosages further confirm this fact where a variation of at least $\pm 10 \%$ against the prescribed dose was observed for the doses analyzed.

In some instances where very small dose divisions were required (eg.1/25 of a $25 \mathrm{mg}$ tablet to give $1 \mathrm{mg}$ or $1 / 10$ of a $40 \mathrm{mg}$ frusemide tablet to give $4 \mathrm{mg}$ ), one tablet or part of a tablet was dissolved in a known volume of water from which the volume containing the required amount of drug was obtained and administered to the patient. The accuracy of this method is in question because only a few drugs are water soluble and simply dissolving the tablet in water does not ensure the availability of the active ingredient in the volume obtained for administration. The preparation of oral solutions or suspensions from tablets and capsules requires more technical input and support from the pharmacy staff.

Administration of inaccurate doses for IV drugs was largely due to negligence. The nurse calculated the volume of drug to be administered mentally and this was administered without further verification. Errors were mainly recorded for gentamicin sulphate injection containing $80 \mathrm{mg}$ of gentamicin in $2 \mathrm{ml}$ and benzylpenicillin sodium containing $600 \mathrm{mg}$ (1MU) of benzylpenicillin in $4 \mathrm{ml}$ when reconstituted. For these two drugs the calculation of the accurate volume to be administered is somewhat difficult to carry out mentally. Thus, to ensure dose accuracy, it is recommended that a calculator be always present on the drug trolley to calculate the accurate volume required, especially when the volume to be administered is not obvious. In addition, it is important that the paediatrician is aware of the dosages available and the dose conversions that are required to be made for each drug prescribed and round off the dose to a convenient amount/volume that gives the nearest dose1. This would help relieve the burden on the nursing staff when calculating paediatric doses.

Administration of repeated inaccurate doses to patients may result in toxicities due to over dosage while under dosage may result in treatment failure. However there were no adverse outcomes noted in the patients observed during the study. In addition, repetitive administration of inaccurate doses was not recorded. In the eight hourly administration frequency of antibiotics it was clear that proper spacing of the drugs was not carried out. The recommended times on the BHTs were 7 a.m., 3 p.m., and 11 p.m. However the actual times of drug administration were 8.30 a.m., 2.30 p.m., and 8.30 p.m. Thus there was a period of 'over exposure' $(6-61 / 2$ hours) and a period of 'under exposure' (111/2 - 12 hours) of the drug in the patient rather than the prescribed eight hourly spacing. Therefore an additional drug round at around 11 p.m. is recommended to administer the final dose of the day so that the fluctuations can be minimized.

\section{Conclusions}

The nursing staff at ward 01, Lady Ridgeway Hospital, Colombo were found to be competent in most aspects of drug administration. However, more commitment was necessary especially in the conversion of adult dosage forms to paediatric doses and in the calculation of the correct volume of medication in IV therapy. Availability of liquid oral preparations instead of converted adult dosages would help reduce the incidence of administration of inaccurate doses. As the conversion of adult dosage forms to paediatric doses is an additional burden bestowed upon the nursing staff in paediatric units and since the preparation of inaccurate doses is a tedious process, conscientious technical support from the pharmacy staff is advocated.

\section{Acknowledgements}

We thank Dr. R. Wimal Jayantha, Director, Lady Ridgeway Hospital, Colombo for giving permission to undertake the project, the management of the State Pharmaceutical Manufacturing Corporation (SPMC), Ratmalana and particularly Mr. Athula Kuruppu, Quality Control Manager and his staff for the help provided in carrying out the analytical work. Thanks are also due to Dr. G. Sathiadas, Temporary Lecturer, Department of Paediatrics, Faculty of Medicine, University of Colombo.

\section{References}

1. Brown T. R., and Smith M. C. Paediatrics, Handbook of institutional pharmacy practice 2nd ed., Baltimore 1986; 516-1.

2. Membership of the British Pharmacopoeia commission, Brithish Pharmacopoeia 2000; II: 1974 - 1975, 1837.

3. Membership of the European Pharmacopoeia commission, British Pharmacopoeia 1988; II: 1001. 
